\title{
Vaporization and Thermodynamics of Glass-Forming Oxide Melts: Mass Spectrometric Study and Modeling
}

\author{
V. L. Stolyarova \\ Institute of Chemistry, Saint Petersburg State University, Saint Petersburg, Russian Federation \\ Email: stvl08@inbox.ru
}

Received 1 April 2015; accepted 24 June 2015; published 1 July 2015

\begin{abstract}
Information on the vaporization processes and thermodynamic properties of glass-forming oxide melts in the systems $\mathrm{MgO}-\mathrm{B}_{2} \mathrm{O}_{3}-\mathrm{SiO}_{2}, \mathrm{CaO}-\mathrm{B}_{2} \mathrm{O}_{3}-\mathrm{SiO}_{2}, \mathrm{SrO}-\mathrm{B}_{2} \mathrm{O}_{3}-\mathrm{SiO}_{2}, \mathrm{BaO}-\mathrm{B}_{2} \mathrm{O}_{3}-\mathrm{SiO}_{2}, \mathrm{PbO}-\mathrm{B}_{2} \mathrm{O}_{3}-\mathrm{SiO}_{2}$, $\mathrm{CdO}-\mathrm{B}_{2} \mathrm{O}_{3}-\mathrm{SiO}_{2}, \mathrm{ZnO}-\mathrm{B}_{2} \mathrm{O}_{3}-\mathrm{SiO}_{2}, \mathrm{Bi}_{2} \mathrm{O}_{3}-\mathrm{B}_{2} \mathrm{O}_{3}-\mathrm{SiO}_{2}$ and $\mathrm{Bi}_{2} \mathrm{O}_{3}-\mathrm{GeO}_{2}-\mathrm{SiO}_{2}$ together with the earlier obtained data is discussed. These data were obtained by high-temperature mass spectrometric method. Various types of vapor species were found over oxide systems studied such as the associated, dissociated and polymerized products of vaporization. The regularities of the vaporization of the binary and multicomponent glass-forming oxide melts were illustrated and discussed from the point of view of the acid-base concept. Results on determination of thermodynamic functions in oxide systems were considered taking into account the main requirements for the confirmation of their reliability. The generalized lattice theory of associated solutions was used for the calculation of thermodynamic properties of the ternary silicate melts studied. Using this approach the different levels of deviations from the ideality in the melts under investigation were clarified. The relative numbers of bonds of various types formed in the melts considered were also calculated based on the generalized lattice theory of associated solutions.
\end{abstract}

\section{Keywords}

Glass-Forming Oxide Melts, Thermodynamics, Vaporization, High Temperature Mass Spectrometry

\section{Introduction}

Development of the advanced glass materials requires the reliable information on vaporization processes and thermodynamic properties of glass-forming melts. This paper presents the review on the recent data obtained by Knudsen effusion mass spectrometric method on high temperature behavior of glass-forming oxide melts in the systems MgO- $\mathrm{B}_{2} \mathrm{O}_{3}-\mathrm{SiO}_{2}, \mathrm{CaO}-\mathrm{B}_{2} \mathrm{O}_{3}-\mathrm{SiO}_{2}, \mathrm{SrO}-\mathrm{B}_{2} \mathrm{O}_{3}-\mathrm{SiO}_{2}, \mathrm{BaO}-\mathrm{B}_{2} \mathrm{O}_{3}-\mathrm{SiO}_{2}, \mathrm{PbO}-\mathrm{B}_{2} \mathrm{O}_{3}-\mathrm{SiO}_{2}, \mathrm{CdO}-\mathrm{B}_{2} \mathrm{O}_{3}-\mathrm{SiO}_{2}$, $\mathrm{ZnO}-\mathrm{B}_{2} \mathrm{O}_{3}-\mathrm{SiO}_{2}, \mathrm{Bi}_{2} \mathrm{O}_{3}-\mathrm{B}_{2} \mathrm{O}_{3}-\mathrm{SiO}_{2}$ and $\mathrm{Bi}_{2} \mathrm{O}_{3}-\mathrm{GeO}_{2}-\mathrm{SiO}_{2}$. The systems under study have the wide range of practical applications in the production of glasses, enamels, glazers and ceramics as well as in the various high tem- 
perature technologies such as incorporation of nuclear wastes, obtaining of optical fibers and others. It was evidently shown [1] that Knudsen effusion mass spectrometric method is extremely powerful tool to study vaporization processes and thermodynamic properties of glass-forming oxide systems since this approach was suggested first [2] for the investigation of individual compounds. Recent advantages and improvements of this experimental technique may be found in [3]. Unfortunately one of the latest reviews on mass spectrometric study of inorganic compounds and materials at high temperatures [4] did not draw too much attention to glass-forming materials. This paper is an effort to meet this lack. In details the unique opportunities and features of high temperature mass spectrometric method for study of the vaporization processes and thermodynamic properties of oxide systems and materials are summarized in [1] [5]-[8]. It was illustrated that the main regularities of the vaporization of oxide systems were in agreement with the acid-based concept of interactions in the oxide melts. It was also repeatedly illustrated that the results on determination of thermodynamic functions in oxide systems were satisfied the main requirements for the confirmation of their reliability in comparison with data obtained by the electromotive force method and the high temperature solution calorimetric method.

\section{Experimental}

High-temperature Knudsen effusion mass spectrometry was used to study vaporization processes and to determine the partial pressures of vapor species as well as the component activities of the $\mathrm{MgO}-\mathrm{B}_{2} \mathrm{O}_{3}-\mathrm{SiO}_{2}$, CaO$\mathrm{B}_{2} \mathrm{O}_{3}-\mathrm{SiO}_{2}, \mathrm{SrO}-\mathrm{B}_{2} \mathrm{O}_{3}-\mathrm{SiO}_{2}, \mathrm{BaO}-\mathrm{B}_{2} \mathrm{O}_{3}-\mathrm{SiO}_{2}, \mathrm{PbO}-\mathrm{B}_{2} \mathrm{O}_{3}-\mathrm{SiO}_{2}, \mathrm{CdO}-\mathrm{B}_{2} \mathrm{O}_{3}-\mathrm{SiO}_{2}, \mathrm{ZnO}-\mathrm{B}_{2} \mathrm{O}_{3}-\mathrm{SiO}_{2}, \mathrm{Bi}_{2} \mathrm{O}_{3}-\mathrm{B}_{2} \mathrm{O}_{3}-$ $\mathrm{SiO}_{2}$ and $\mathrm{Bi}_{2} \mathrm{O}_{3}-\mathrm{GeO}_{2}-\mathrm{SiO}_{2}$ melts [9]-[18]. Measurements were performed with MS-1301 mass spectrometer developed by the Institute of Analytical Instrumentation of the Russian Academy of Sciences, Saint Petersburg, Russia. Vaporization was carried out using two effusion cells containing the sample under study and pure oxide (reference substance). The main part of experiments were done from molybdenum effusion cells except the $\mathrm{PbO}-\mathrm{B}_{2} \mathrm{O}_{3}-\mathrm{SiO}_{2}$ system when vaporization was carried out from quartz effusion cells [14]-[16] as well as except the $\mathrm{Bi}_{2} \mathrm{O}_{3}-\mathrm{B}_{2} \mathrm{O}_{3}-\mathrm{SiO}_{2}$ and $\mathrm{Bi}_{2} \mathrm{O}_{3}-\mathrm{GeO}_{2}-\mathrm{SiO}_{2}$ systems when the iridium-plated molybdenum effusion cells were used [17] [18]. Ions were produced by electron ionization at an energy of $25 \mathrm{eV}$. To facilitate interpretation of mass spectra of vapor over glass-forming melts under consideration the appearance energies of ions were also measured. The installation was calibrated using the vapor pressure of gold, recommended by IUPAC as the standard.

\section{Results and Discussion}

Various types of vapor species were found over the glass-forming melts of the $\mathrm{MgO}-\mathrm{B}_{2} \mathrm{O}_{3}-\mathrm{SiO}_{2}, \mathrm{CaO}-\mathrm{B}_{2} \mathrm{O}_{3}-\mathrm{SiO}_{2}$, $\mathrm{SrO}-\mathrm{B}_{2} \mathrm{O}_{3}-\mathrm{SiO}_{2}, \mathrm{BaO}-\mathrm{B}_{2} \mathrm{O}_{3}-\mathrm{SiO}_{2}, \mathrm{PbO}-\mathrm{B}_{2} \mathrm{O}_{3}-\mathrm{SiO}_{2}, \mathrm{CdO}-\mathrm{B}_{2} \mathrm{O}_{3}-\mathrm{SiO}_{2}, \mathrm{ZnO}-\mathrm{B}_{2} \mathrm{O}_{3}-\mathrm{SiO}_{2}, \mathrm{Bi}_{2} \mathrm{O}_{3}-\mathrm{B}_{2} \mathrm{O}_{3}-\mathrm{SiO}_{2}$ and $\mathrm{Bi}_{2} \mathrm{O}_{3}-\mathrm{GeO}_{2}-\mathrm{SiO}_{2}$ systems studied [9]-[18] such as the associated and dissociated products of vaporization, Ta-

ble 1. It should be underlined that the composition of vapor found over these melts was in agreement with the

Table 1. Composition of vapor over ternary glass-forming oxide melts studied by high temperature mass spectrometric method [9]-[18].

\begin{tabular}{|c|c|c|c|}
\hline \multirow{2}{*}{ System under study } & \multicolumn{3}{|c|}{ Composition of vapor at the temperature indicated } \\
\hline & Temperature, K & Composition of vapor & References \\
\hline $\mathrm{MgO}-\mathrm{B}_{2} \mathrm{O}_{3}-\mathrm{SiO}_{2}$ & $1550-1800$ & $\mathrm{~B}_{2} \mathrm{O}_{3}, \mathrm{SiO}, \mathrm{MgB}_{2} \mathrm{O}_{4}, \mathrm{MoO}_{2}, \mathrm{MoO}_{3}$ & {$[9]$} \\
\hline $\mathrm{CaO}-\mathrm{B}_{2} \mathrm{O}_{3}-\mathrm{SiO}_{2}$ & 1800 & $\mathrm{~B}_{2} \mathrm{O}_{3}, \mathrm{SiO}, \mathrm{CaB}_{2} \mathrm{O}_{4}, \mathrm{MoO}_{2}, \mathrm{MoO}_{3}$ & {$[10][11]$} \\
\hline $\mathrm{SrO}-\mathrm{B}_{2} \mathrm{O}_{3}-\mathrm{SiO}_{2}$ & $1720-1800$ & $\mathrm{~B}_{2} \mathrm{O}_{3}, \mathrm{SiO}, \mathrm{SrB}_{2} \mathrm{O}_{4}, \mathrm{MoO}_{2}, \mathrm{MoO}_{3}$ & {$[11][12]$} \\
\hline $\mathrm{BaO}-\mathrm{B}_{2} \mathrm{O}_{3}-\mathrm{SiO}_{2}$ & $1650-1730$ & $\mathrm{~B}_{2} \mathrm{O}_{3}, \mathrm{SiO}, \mathrm{BaB}_{2} \mathrm{O}_{4}, \mathrm{MoO}_{2}, \mathrm{MoO}_{3}$ & {$[11][13]$} \\
\hline $\mathrm{PbO}-\mathrm{B}_{2} \mathrm{O}_{3}-\mathrm{SiO}_{2}$ & 1100 & $\mathrm{PbO}, \mathrm{Pb}, \mathrm{O}_{2}$ & {$[14]-[16]$} \\
\hline $\mathrm{ZnO}-\mathrm{B}_{2} \mathrm{O}_{3}-\mathrm{SiO}_{2}$ & 1250 & $\mathrm{Zn}, \mathrm{O}_{2}$ & {$[15]-[17]$} \\
\hline $\mathrm{CdO}-\mathrm{B}_{2} \mathrm{O}_{3}-\mathrm{SiO}_{2}$ & 1023 & $\mathrm{Cd}, \mathrm{O}_{2}$ & [16] [17] \\
\hline $\mathrm{Bi}_{2} \mathrm{O}_{3}-\mathrm{B}_{2} \mathrm{O}_{3}-\mathrm{SiO}_{2}$ & 1000 & $\mathrm{Bi}, \mathrm{O}_{2}$ & {$[17]$} \\
\hline $\mathrm{Bi}_{2} \mathrm{O}_{3}-\mathrm{GeO}_{2}-\mathrm{SiO}_{2}$ & 1200 & $\mathrm{Bi}, \mathrm{O}_{2}$ & [18] \\
\hline
\end{tabular}


content of gaseous phase during vaporization of corresponding binary systems [1] and corresponding gaseous salts that were identified over them [19]. The main feature of thermodynamic description of glass-forming melts under study was the negative deviations from the ideal behavior. As examples Figure 1 and Figure 2 illustrate some of the recent experimental thermodynamic data obtained in the melts of the $\mathrm{Bi}_{2} \mathrm{O}_{3}-\mathrm{B}_{2} \mathrm{O}_{3}-\mathrm{SiO}_{2}$ and $\mathrm{Bi}_{2} \mathrm{O}_{3}-$ $\mathrm{GeO}_{2}-\mathrm{SiO}_{2}$ systems [17] [18]. The concentration dependences of the $\mathrm{Bi}_{2} \mathrm{O}_{3}$ isoactivity curves in $\mathrm{Bi}_{2} \mathrm{O}_{3}-\mathrm{B}_{2} \mathrm{O}_{3}$ $\mathrm{SiO}_{2}$ melts at the temperature $1200 \mathrm{~K}$ [17] are presented on Figure 1. It is very important to mention that the level of the deviations of thermodynamic properties from the ideal behavior in the glass-forming melts considered was in agreement with the acid-base concept of interactions in oxide melts [1] and depended on the basicity of the melts (as in the case of the $\mathrm{CaO}-\mathrm{B}_{2} \mathrm{O}_{3}-\mathrm{SiO}_{2}, \mathrm{SrO}-\mathrm{B}_{2} \mathrm{O}_{3}-\mathrm{SiO}_{2}, \mathrm{BaO}-\mathrm{B}_{2} \mathrm{O}_{3}-\mathrm{SiO}_{2}$ systems [10]-[13]) or on the acidity of the melts (as in the case of $\mathrm{Bi}_{2} \mathrm{O}_{3}-\mathrm{B}_{2} \mathrm{O}_{3}-\mathrm{SiO}_{2}$ and $\mathrm{Bi}_{2} \mathrm{O}_{3}-\mathrm{GeO}_{2}-\mathrm{SiO}_{2}$ systems [15]-[18], Figure 2). Modeling of thermodynamic properties of glass-forming melts in the $\mathrm{MgO}-\mathrm{B}_{2} \mathrm{O}_{3}-\mathrm{SiO}_{2}, \mathrm{CaO}-\mathrm{B}_{2} \mathrm{O}_{3}-\mathrm{SiO}_{2}$, SrO$\mathrm{B}_{2} \mathrm{O}_{3}-\mathrm{SiO}_{2}, \mathrm{BaO}-\mathrm{B}_{2} \mathrm{O}_{3}-\mathrm{SiO}_{2}, \mathrm{PbO}-\mathrm{B}_{2} \mathrm{O}_{3}-\mathrm{SiO}_{2}, \mathrm{CdO}-\mathrm{B}_{2} \mathrm{O}_{3}-\mathrm{SiO}_{2}, \mathrm{ZnO}-\mathrm{B}_{2} \mathrm{O}_{3}-\mathrm{SiO}_{2}, \mathrm{Bi}_{2} \mathrm{O}_{3}-\mathrm{B}_{2} \mathrm{O}_{3}-\mathrm{SiO}_{2}$ and $\mathrm{Bi}_{2} \mathrm{O}_{3}-$ $\mathrm{GeO}_{2}-\mathrm{SiO}_{2}$ systems was done using the generalized lattice theory of associated solutions (GLTAS) described in details for the application for glass-forming melts earlier in [1]. This approach is suggested by Barker [20] for modeling of organic mixtures and may be represented by the Guggenheim model of the strongly regular solutions in the systems where molecules differs on the sizes and their interaction energy depends on mutual orientation of the molecules. Peculiarities of description of this model to glass-forming melts under consideration may be found in [21]-[23] including the features of introduction of $\mathrm{Bi}_{2} \mathrm{O}_{3}$ in the structure of melt as in [24]. Thus the mutual agreement of thermodynamic properties of glass-forming oxide melts containing one oxide modifier and two glass-forming oxides (as in the present case) was repeatedly shown as the result of comparison of such modeling and experimental data obtained by high temperature mass spectrometric method. As an example of this fact Figure 1 shows the mutual correlation between experimental values of the $\mathrm{Bi}_{2} \mathrm{O}_{3}$ activities obtained in $\mathrm{Bi}_{2} \mathrm{O}_{3}-\mathrm{B}_{2} \mathrm{O}_{3}-\mathrm{SiO}_{2}$ melts and results of modeling based on GLTAS at the temperature $1200 \mathrm{~K}$ [17]. One of the advantages of GLTAS model is the opportunity to find the correspondence between the changes of thermodynamic properties of glass-forming melt and its structure such as the relative number of bonds of different types formed in the melt when the second coordination sphere is taken into consideration. As it was mentioned above and shown on Figure 2 in $\mathrm{Bi}_{2} \mathrm{O}_{3}-\mathrm{B}_{2} \mathrm{O}_{3}-\mathrm{SiO}_{2}$ melts the most negative deviations from the ideality was observed

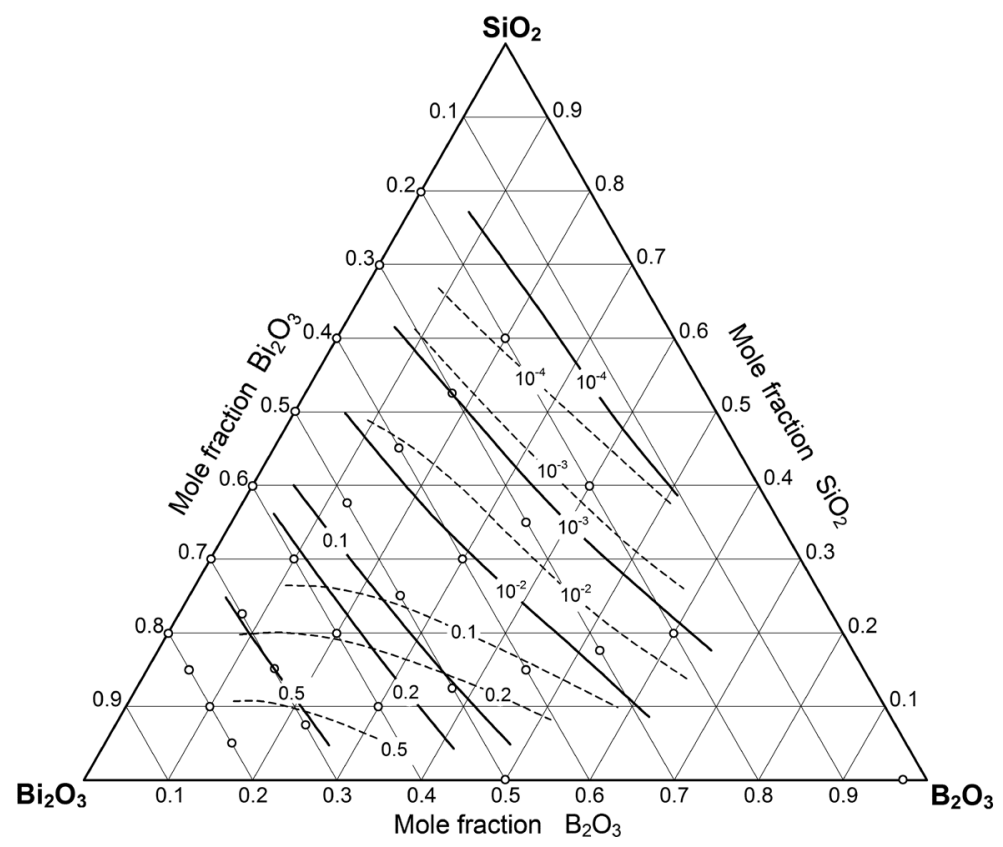

Figure 1. The $\mathrm{Bi}_{2} \mathrm{O}_{3}$ isoactivity lines in $\mathrm{Bi}_{2} \mathrm{O}_{3}-\mathrm{B}_{2} \mathrm{O}_{3}-\mathrm{SiO}_{2}$ melt at the temperature $1200 \mathrm{~K}$ [17]. Solid lines indicate the results of modeling using GLTAS, dashed lines are experimental results obtained by high temperature mass spectrometric method. The numbers at the contour lines are the values of the $\mathrm{Bi}_{2} \mathrm{O}_{3}$ activity. 


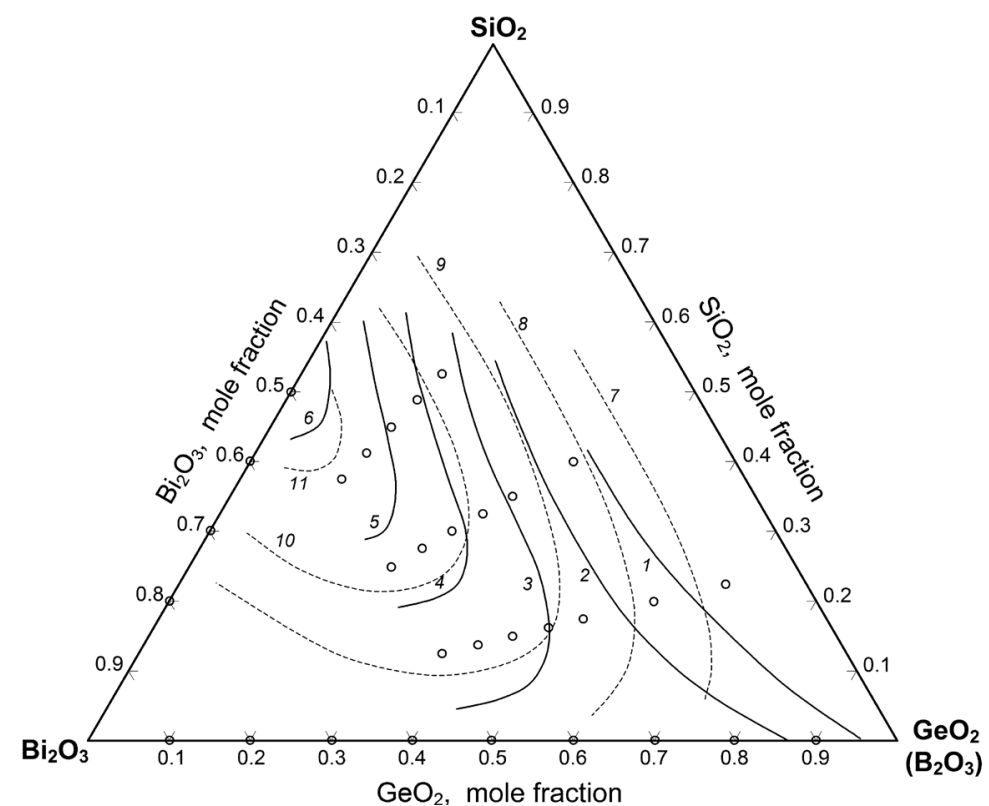

Figure 2. Comparison of the excess Gibbs energy in the melts of the $\mathrm{Bi}_{2} \mathrm{O}_{3}$ $\mathrm{GeO}_{2}-\mathrm{SiO}_{2}$ system (solid lines) [18] and in the melts of the $\mathrm{Bi}_{2} \mathrm{O}_{3}-\mathrm{B}_{2} \mathrm{O}_{3}-\mathrm{SiO}_{2}$ system (dashed lines) [17] at the temperature $1200 \mathrm{~K}$ calculated according to GLTAS. Numbers in the triangle indicate the corresponding values of $\left(-\Delta \mathrm{G}^{\mathrm{E}}\right)$, $\mathrm{kJ} / \mathrm{mol}: 1-5,2-10,3-15,4-20,5-25,6-30,7-15,8-20,9-25$, $10-30,11-35$.

compared with $\mathrm{Bi}_{2} \mathrm{O}_{3}-\mathrm{GeO}_{2}-\mathrm{SiO}_{2}$ melts. As the results of modeling using GLTAS information on the relative numbers of bonds in these melts may be also found [20]-[24]. The data obtained [17] [18] allows concluding that the $\mathrm{Bi}-\mathrm{O}-\mathrm{Si}$ bonds have the predominant role in the formation of the $\mathrm{Bi}_{2} \mathrm{O}_{3}-\mathrm{B}_{2} \mathrm{O}_{3}-\mathrm{SiO}_{2}$ and $\mathrm{Bi}_{2} \mathrm{O}_{3}-\mathrm{GeO}_{2}-\mathrm{SiO}_{2}$ melts with the negative deviations from the ideality. As the molar ratio of $\mathrm{B}_{2} \mathrm{O}_{3}\left(\mathrm{GeO}_{2}\right): \mathrm{SiO}_{2}$ decreases the influence of $\mathrm{Bi}-\mathrm{O}-\mathrm{Ge}$ and $\mathrm{Bi}-\mathrm{O}-\mathrm{Si}$ bonds on the negative deviations from the ideality of these melts is more valid. The features of structural description of these glass-forming melts obtained as the result of modeling were successfully confirmed using X-ray scattering method [25]-[27].

\section{Conclusion}

Using high temperature Knudsen effusion mass spectrometric method it is shown that the composition of vapor over the MgO- $\mathrm{B}_{2} \mathrm{O}_{3}-\mathrm{SiO}_{2}, \mathrm{CaO}-\mathrm{B}_{2} \mathrm{O}_{3}-\mathrm{SiO}_{2}, \mathrm{SrO}-\mathrm{B}_{2} \mathrm{O}_{3}-\mathrm{SiO}_{2}, \mathrm{BaO}-\mathrm{B}_{2} \mathrm{O}_{3}-\mathrm{SiO}_{2}, \mathrm{PbO}-\mathrm{B}_{2} \mathrm{O}_{3}-\mathrm{SiO}_{2}, \mathrm{CdO}-\mathrm{B}_{2} \mathrm{O}_{3}-\mathrm{SiO}_{2}$, $\mathrm{ZnO}-\mathrm{B}_{2} \mathrm{O}_{3}-\mathrm{SiO}_{2}, \mathrm{Bi}_{2} \mathrm{O}_{3}-\mathrm{B}_{2} \mathrm{O}_{3}-\mathrm{SiO}_{2}$ and $\mathrm{Bi}_{2} \mathrm{O}_{3}-\mathrm{GeO}_{2}-\mathrm{SiO}_{2}$ melts are in agreement with the content of gaseous phase over corresponding binary systems. In the ternary glass-forming melts studied the negative deviations from the ideal behavior were found that were in agreement with the main statements of the acid-base concept. Reliability of application of the generalized lattice theory of associated solutions for modeling of thermodynamic properties and structural features of ternary glass-forming melts with one oxide modifier was illustrated.

\section{Acknowledgements}

Financial support for this work from the Russian Fund for Basic Research according to the Project N 13-0300718 and from Saint Petersburg State University according to the Project N 12.41.937.2015 is gratefully acknowledged.

\section{References}

[1] Stolyarova, V. and Semenov, G. (1994) Mass Spectrometric Study of the Vaporization of Oxide Systems. 2nd Revised Edition with Addenda, John Wiley \& Sons Ltd., Chichester.

[2] Inghram, M.G. and Drowart, J. (1959) Mass Spectrometry Applied to High Temperature Chemistry. Proceedings of 
International Symposium on High Temperature Technology, Asilomar, 1959, 219-240.

[3] Drowart, J., Chatillon, C., Hastie, J. and Bonnell, D. (2005) High-Temperature Mass Spectrometry: Instrumental Techniques, Ionization Cross-Sections, Pressure Measurements, and Thermodynamic Data. Pure and Applied Chemistry, 77, 683-737. http://dx.doi.org/10.1351/pac200577040683

[4] Miller, M. and Armatys, K. (2013) Twenty Years of Knudsen Effusion Mass Spectrometry: Studies Performed in the Period 1990-2010. The Open Thermodynamics Journal, 7, 2-9. http://dx.doi.org/10.2174/1874396X01307010002

[5] Stolyarova, V.L. (2001) A Mass Spectrometric Study of the Thermodynamic Properties of Oxide Melts. Glass Physics and Chemistry, 27, 3-15. http://dx.doi.org/10.1023/A:1009599502138

[6] Stolyarova, V.L. (2013) High Temperature Mass Spectrometric Study of Thermodynamic Properties and Vaporization Processes of Oxide Systems: Experiment and Modeling. The Open Thermodynamics Journal, 7, 57-70. http://dx.doi.org/10.2174/1874396X01307010057

[7] Stolyarova, V.L. (2013) Vaporization Processes and Thermodynamic Properties of Oxide Systems Studied by High Temperature Mass Spectrometry. ECS Transactions, 46, 55-68. http://dx.doi.org/10.1149/04601.0055ecst

[8] Stolyarova, V.L. (2008) Thermodynamic Properties and Structure of Ternary Silicate Glass-Forming Melts: Experimental Studies and Modeling. Journal of Non-Crystalline Solids, 354, 1373-1377. http://dx.doi.org/10.1016/j.jnoncrysol.2006.10.087

[9] Stolyarova, V.L., Lopatin, S.I., Shugurov, S.M. and Shilov, A.L. (2010) Thermodynamic Properties of Silicate Glasses and Melts: VII. System MgO- $\mathrm{B}_{2} \mathrm{O}_{3}-\mathrm{SiO}_{2}$. Russian Journal of General Chemistry, 80, 2405-2413. http://dx.doi.org/10.1134/S1070363210120029

[10] Stolyarova, V.L., Lopatin, S.I. and Shugurov, S.M. (2008) Thermodynamic Properties of Silicate Glasses and Melts: V. Systems $\mathrm{CaB}_{2} \mathrm{O}_{4}-\mathrm{CaSiO}_{3}$ and $\mathrm{Ca}_{2} \mathrm{~B}_{2} \mathrm{O}_{5}-\mathrm{CaSiO}_{3}$. Russian Journal of General Chemistry, 78, 1877-1881. http://dx.doi.org/10.1134/S1070363208100083

[11] Stolyarova, V.L. and Lopatin, S.I. (2010) Thermodynamic Properties of Borosilicate Melts Containing Alkaline-Earth Oxides. Vestnik KGTU, 98-101.

[12] Stolyarova, V.L., Lopatin, S.I. and Shilov, A.L. (2009) Thermodynamic Properties of Silicate Glasses and Melts: VI. System SrO- $\mathrm{B}_{2} \mathrm{O}_{3}-\mathrm{SiO}_{2}$. Russian Journal of General Chemistry, 79, 1778-1784. http://dx.doi.org/10.1134/S1070363209090035

[13] Tyurnina, Z.G., Lopatin, S.I. and Stolyarova, V.L. (2008) Thermodynamic Properties of Silicate Glasses and Melts: IV. System $\mathrm{BaO}-\mathrm{B}_{2} \mathrm{O}_{3}-\mathrm{SiO}_{2}$. Russian Journal of General Chemistry, 78, 14-18. http://dx.doi.org/10.1134/S1070363208010039

[14] Stolyarova, V.L., Lopatin, S.I., Shilov, A.L. and Shugurov, S.M. (2013) High-Temperature Mass Spectrometric Study of the Vaporization Processes and Thermodynamic Properties of Melts in the $\mathrm{PbO}-\mathrm{B}_{2} \mathrm{O}_{3}-\mathrm{SiO}_{2} \mathrm{System}$. Rapid Communications in Mass Spectrometry, 27, 1559-1566. http://dx.doi.org/10.1002/rcm.6606

[15] Stolyarova, V.L., Lopatin, S.I., Shilov, A.L. and Shugurov, S.M. (2011) Thermodynamic Properties of Melts in the $\mathrm{PbO}-\mathrm{B}_{2} \mathrm{O}_{3}-\mathrm{SiO}_{2}$ and $\mathrm{ZnO}-\mathrm{B}_{2} \mathrm{O}_{3}-\mathrm{SiO}_{2}$ Systems: Experimental Study and Modeling. 25th European Symposium on Applied Thermodynamics, ESAT 2011, Book of Abstracts, Saint Petersburg, 24-27 June 2011, 296.

[16] Stolyarova, V.L., Lopatin, S.I., Shilov, A.L. and Shugurov, S.M. (2013) Thermodynamic Properties of Borosilicate Glasses and Melts Containing Oxides of Heavy Metals (Cd, Zn, Pb). XIX International Conference on Chemical Thermodynamics in Russia, Abstracts, Moscow, 24-28 June 2013, 318.

[17] Stolyarova, V.L., Lopatin, S.I., Shilov, A.L. and Shugurov, S.M. (2013) Application of Knudsen Effusion Mass Spectrometric Method for Environmental Science: Vaporization of Heavy Metals from Borosilicate Melts. Innovation in Mass Spectrometry Instrumentation Conference, Book of Abstracts, Saint Petersburg, 14-18 July 2013, 54-55.

[18] Stolyarova, V.L., Lopatin, S.I., Shugurov, S.M. and Shilov, A.L. (2014) Thermodynamic Properties of Glasses in the $\mathrm{Bi}_{2} \mathrm{O}_{3}-\mathrm{GeO}_{2}-\mathrm{SiO}_{2}$ System. Proceedings of XIV Russian Conference (with International Participation) on Thermo Physical Properties of Substances (RCTP-14), Kazany, 15-17 October 2014, 251-253.

[19] Lopatin, S.I. and Stolyarova, V.L. (2006) Thermodynamic Properties and Structure of Gaseous Metaborates. Glass Physics and Chemistry, 32, 353-369. http://dx.doi.org/10.1134/S1087659606030163

[20] Barker, J.A. (1952) Cooperative Orientation Effects in Solutions. Journal of Chemical Physics, 20, 1526-1532. http://dx.doi.org/10.1063/1.1700209

[21] Stolyarova, V.L. and Shilov, A.L. (2010) Modeling of Thermodynamic Properties and Structure of Borosilicate Melts Using High Temperature Mass Spectrometric Data. Proceedings of the 6th International Conference on Mathematical Modeling and Computer Simulation of Materials Technologies MMT-2010, Ariel, 23-27 August 2010, 1-56-1-64.

[22] Shilov, A.L. and Stolyarova, V.L. (2010) Simulation of Thermodynamic Properties of Borosilicate Melts Containing Alkaline-Earth Metal Oxides. Russian Journal of General Chemistry, 80, 2414-2424.

http://dx.doi.org/10.1134/S1070363210120030 
[23] Stolyarova, V.L. and Shilov, A.L. (2013) Application of the Barker Lattice Theory to Modeling of Thermodynamic Properties of $\mathrm{PbO}-\mathrm{B}_{2} \mathrm{O}_{3}-\mathrm{SiO}_{2}$ Melts. Journal of Non-Crystalline Solids, 366, 6-12. http://dx.doi.org/10.1016/j.jnoncrysol.2013.01.036

[24] Stolyarova, V.L., Shilov, A.L., Lopatin, S.I. and Shugurov, S.M. (2014) High-Temperature Mass Spectrometric Study and Modeling of Thermodynamic Properties of Binary Glass-Forming Systems Containing $\mathrm{Bi}_{2} \mathrm{O}_{3}$. Rapid Communications in Mass Spectrometry, 28, 801-810. http://dx.doi.org/10.1002/rcm.6842

[25] Golubkov, V.V., Tyurnina, N.G., Tyurnina, Z.G. and Stolyarova, V.L. (2009) On the Fluctuation Structure of SinglePhase Glasses in the $\mathrm{SrO}-\mathrm{B}_{2} \mathrm{O}_{3}-\mathrm{SiO}_{2}$ System. Glass Physics and Chemistry, 35, 455-462. http://dx.doi.org/10.1134/S1087659609050010

[26] Golubkov, V.V., Stolyarova, V.L., Tyurnina, Z.G. and Tyurnina, N.G. (2010) On the Structure of Glasses in the BaO$\mathrm{B}_{2} \mathrm{O}_{3}-\mathrm{SiO}_{2}$ System. Glass Physics and Chemistry, 36, 554-560. http://dx.doi.org/10.1134/S1087659610050020

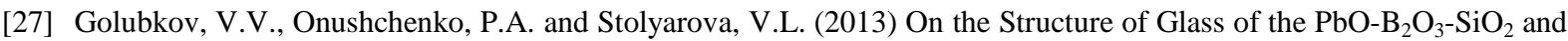
CdO- $\mathrm{B}_{2} \mathrm{O}_{3}-\mathrm{SiO}_{2}$ Systems. Glass Physics and Chemistry, 39, 624-633. http://dx.doi.org/10.1134/S1087659613060059 